\title{
The Strategies Competitiveness for Yogyakarta Tourism Industry
}

\author{
Jumadi ${ }^{1}$, Cahya Purnama Asri ${ }^{2}$, Bahri ${ }^{3}$ \\ \{jumadi@widyamataram.ac.id ${ }^{1}$, cahyapurnama.uwm@gmail.com² , bahri@widyamataram.ac.id ${ }^{3}$ \} \\ Department Management Economics Faculty of Widya Mataram University ${ }^{1}$ \\ Department Entrepreneurship Economics Faculty of Widya Mataram University 2,3
}

\begin{abstract}
Yogyakarta is the second wonderful destination in Indonesia after Bali, aim to this paper to Kwon Yogyakarta Tourism Strategies. This paper aims to contribute to the tourism industry in Yogyakarta. The methodology used is the AttractivenessCompetitiveness Matrix. This model is expected to be used in helping make policies to determine the priority scale of tourism development in Yogyakarta. The manuscript presents a matrix, describes how the matrix is used to help Tourism prioritize the Strategy. Based on the SWOT Matrix studied, an alternative strategy was formulated in the Yogyakarta tourism industry are: Branding Yogyakarta tourism destination, Satisfaction tourism strategy, tourism-based heritage, and culture, building the optimization of promotion with government support, human and technology development, developing public transportation and safety facilities of tourism, the complete package of several facilities options and development tourist attractions such as art performances.
\end{abstract}

Keywords: Tourism strategy Tourism set priorities strategy, Competitiveness situation analysis (SWOT), Tourist attractions such as art performances

\section{Introduction}

Rural Tourism is a complex industry that urgently needs a strategy for directing large numbers of people from different countries with different socio-economic structures who have different needs, tests, attitudes, expectations, and behavior patterns. To achieve a competitive advantage in its tourism industry sector, a destination must ensure that it has a multiplicity of 'attractiveness', and the tourist destinations it offers must have an advantage over other alternative destinations. Potential visitors to any destination are closely tied to the overall competitiveness of that destination (Dwyer and Kim, 2003).

Determination of the level of the competitive position will determine the level of the company's relative position in the competitive arena. This can enable the company to create a more defensible position by formulating and selecting strategies based on strengths, weaknesses, and existing opportunities and threats (Porter 1980, 1985). Competitiveness remains a concept that is not well understood, despite its widely accepted importance of competition at the country, industry, and company levels. Therefore (Moon et al., 1998) provides insights into increasing knowledge and understanding of competitiveness. Dwyer, Forsyth, and Rao (2002) explain that the competitiveness of the tourism sector is a general concept that includes price differences coupled with exchange rate movements and productivity levels of various components of the tourism industry as well as qualitative factors 
that affect attractiveness or other objectives. Meanwhile, Hassan (2000) defines competitiveness as the ability of destinations to create and integrate product strengths that have added value that support their resources while maintaining their market position relative to competitors.

Tourism and destinations that are competitive will attract visitors so that they can increase the socio-cultural, economic, and environmental benefits of the surrounding destinations (Vanhole, 2006; Ritchie \& Crouch, 2005; Armenska, 2011). Tourism that has competitiveness can increase sustainable tourism development, this means that a destination that has competitiveness provides high benefits for the community as its host (Wondowossen. At.al. 2014) Conditions of intense competition amidst globalization, which is strong and the need to survive life has led to an urgent need for management so that competitiveness can be obtained. The concept of competitiveness has been widely understood in almost all industries and countries since Porter published his "Competitive Strategy" in 1980 (Fulad, Kume; 2013). To create competitiveness, this can be done through developing, implementing, and monitoring each initiative with a measurable and understandable framework.

This paper aims to develop models and indicators of the competitiveness of a destination, especially for tourism destinations in Yogyakarta. Yogyakarta is a province of Indonesia which is a developing country in Asia. Tourism in Yogyakarta has experienced a decline due to inadequate and ineffective promotional activities, so a study is needed to produce strategic approaches for tour operators. Yogyakarta as a destination must be able to make tourists aware of things to see, places to stay, and what it has to offer to be done at these tourist attractions. In its development, the Yogyakarta Tourism Industry needs to develop infrastructures such as hotels, resorts, and a strategy that better connects government tourism operators with private business actors to increase joint promotional activities and create a suitable tourism brand. However, in building a brand, ideally, it is not only attractive to tourists but also attractive to international investors to be able to invest (Hossain, 2013), so an effective strategy is needed.

\section{Method}

This study uses qualitative and quantitative approaches with primary and secondary data. Primary data collection techniques are carried out through Focus Group Discussion (FGD) with competent people including consultants, academics, and researchers. Meanwhile, secondary data collection techniques used studies with published literature (local \& international).

\section{Result and Discussions}

\section{The Environmental Monitoring}

The environment is a factor that can influence organizational activities. The external environment is the most important environment that cannot be directly controlled by the organization. The external environment includes the economic environment, political environment, culture, political environment, and technology.

\section{SWOT Analysis}


SWOT analysis is an analysis tool that is equipped with relevant information related to the diagnosis process, and the best indication for developing a marketing strategy and tactics, components in a SWOT analysis include strengths, weaknesses, opportunities, and threats (Midelton at. al 2009). The SWOT analysis method in research uses EFAS-IFAS information, namely analysis of external strategic factors and internal strategic factors

\section{Result}

Environmental Monitoring

The influence of organizational activities is the most important environment that cannot be directly controlled; These environments are Economy, Inflation, Politics, Culture, Technology, and Protection of the Natural Environment. Table 1 shows the results of combining secondary data with primary data obtained through FGD, with academics, businesses, and the Yogyakarta government.

Table 1

Tourism Environmental Industry

\begin{tabular}{|c|c|c|}
\hline Factors of Influence & TRENDS & TOURISM EFFECT \\
\hline $\begin{array}{l}\text { 1. Inflation } \\
\text { Economics }\end{array}$ & $\begin{array}{l}\text { The inflation rate is expected to } \\
\text { reach double-digit }\end{array}$ & $\begin{array}{l}\text { The population will reduce tourism } \\
\text { activities. }\end{array}$ \\
\hline 2. Political turmoil & Social unrest & $\begin{array}{l}\text { Some countries will prohibit their } \\
\text { citizens from traveling }\end{array}$ \\
\hline $\begin{array}{l}\text { 3. Communication Media } \\
\text { Technology }\end{array}$ & $\begin{array}{l}\text { The development of the internet } \\
\text { has an impact on digital tourism }\end{array}$ & $\begin{array}{l}\text { The new alternative to promote } \\
\text { tourism through the homepage and } \\
\text { digital marketing tourism. }\end{array}$ \\
\hline $\begin{array}{l}\text { 4. Sociocultural vacation } \\
\text { time }\end{array}$ & $\begin{array}{l}\text { Tourism activities develop to } \\
\text { overcome burnout }\end{array}$ & Preparation of tourists the needs \\
\hline $\begin{array}{l}\text { 5. Natural Environment } \\
\text { Environmental } \\
\text { protection }\end{array}$ & $\begin{array}{l}\text { Increased public awareness of } \\
\text { environmental } \\
\text { significance }\end{array}$ & $\begin{array}{l}\text { Tourism planning must be more } \\
\text { sensitive to the environment. }\end{array}$ \\
\hline
\end{tabular}

Yogyakarta has places best value destination, tourist attractions comprise, The Sultan Palace, Culture Heritage, Water Castle, Merapi Mountain, Lava Tour, Cave, WaterFall, Malioboro, the traditional market, Zoohistorical sites, resorts, beaches, playgrounds, forest and tourist villages, and animal parks.

The SWOT Analysis of Yogyakarta Tourism Industry

Table 2

SWOT Analysis of Yogyakarta Tourism Industry 

A. The natural beauty and great weather
A. The place for performing arts or performing venues is still lacking
B. A complete package of several facilities
B. Promotion is not maximized options
C. Unique and interesting attractions
C. Lack of souvenir shops
D. Typical arts and culture
D. Price attraction expensive facilities
E. The hospitality of surrounding
E. Human Resources poorer quality communities OPPORTUNITIES THREATS
A. The growth of tourism supply resources
B. Availability of job allowances in the
A. Competition among tourism attraction destination
C. Access to preserve local culture
B. Natural disaster
D. An Emergence of technology
E. Words of mouth promotion
C. Unsavety facilities and infrastructure
D. Lack of public transportation
E. Lack of government support

SWOT Analysis With EFAS - IFAS

SWOT analysis is assessed by two factors, namely using weights and ratings. The score of the total weight score is one, while the ranking scores range from 0-9. Each rank is multiplied by the weight equal to the item score. The following table shows the scores from the EFAS.

Table 3

External of Situation Analysis

\begin{tabular}{cccc}
\hline External Factors & Weight & Rating & $\begin{array}{c}\text { Item } \\
\text { Scores }\end{array}$ \\
\hline
\end{tabular}

\section{OPPORTUNITY}

\begin{tabular}{lrrr}
\hline B. Growth of tourism resources & 0,2 & 7,27 & 1,454 \\
\hline C. Availability of job allowenses in the destination & 0,1 & 5,5 & 0,55 \\
\hline D. Access to preserve local culture & 0,1 & 6,8 & 0,68 \\
\hline E. An Emergence of technology & 0,05 & 6,6 & 0,33 \\
\hline F. Words of mouth promotion & 0,05 & 7,4 & 0,37 \\
\hline Total & 0,5 & & 3,384
\end{tabular}

\section{THREATS}

\begin{tabular}{llrrr} 
B. & Competition among tourism attraction & 0,2 & 6,33 & 1,266 \\
\hline C. & Natural disaster & 0,1 & 6 & 0,6 \\
\hline D. Unsavety facilities and infrastructure & 0,1 & 4,8 & 0,48 \\
\hline E. & Lack of public transportation & 0,05 & 5,8 & 0,29 \\
\hline F. Lack of the government support & 0,05 & 5,87 & 0,2935 \\
\hline Total & 0,5 & & 2,9295 \\
\hline Aggregate & 1 & & 6,3135
\end{tabular}

Based on this SWOT analysis it can be explained that the factors external strategic which consists of opportunities and threats have a score of 6.3135 which means that the External Market Business Attraction means Yogyakarta can anticipate all threats that come well. 
Table. 4

Internal Strategic Situation Analysis

\begin{tabular}{lrrr}
\hline \multicolumn{1}{c}{ Internal Strategic Factors } & Weight & Rating & $\begin{array}{c}\text { Item } \\
\text { Scores }\end{array}$ \\
\hline STRENGTH & & & \\
\hline B. Natural beauty and great weather & 0,2 & 7,9 & 1,58 \\
\hline C. A complete package of several facilities options & 0,1 & 6,9 & 0,69 \\
\hline D. Unique and interesting attractions & 0,1 & 7,06 & 0,706 \\
\hline E. Typical arts and culture & 0,05 & 7,8 & 0,39 \\
\hline F. Hospitality of surrounding communities & 0,05 & 8,4 & 0,42 \\
\hline Total & 0,5 & & 3,786 \\
\hline WEAKNESS & & & \\
\hline B. Lack of tourist attractions such as art performances & 0,2 & 5,9 & 1,18 \\
\hline C. Promotion is not maximized & 0,1 & 6,3 & 0,63 \\
\hline D. Lack of souvenir shops & 0,1 & 5,6 & 0,56 \\
\hline E. Price attraction expensive facilities & 0,05 & 5,6 & 0,28 \\
\hline F. Human Resources poorer quality & 0,05 & 6,1 & 0,305 \\
\hline Total & 0,5 & & 2,955 \\
\hline Aggregate & 1 & & 6,741 \\
\hline
\end{tabular}

Based on the Internal Strategic Analysis which is focused on strengths and weaknesses, a score of 6.741 shows that the more competitive internal-Business Strength / Competitive Position means that the business is getting stronger and the attractiveness of the industry is getting higher.

Therefore, based on the SWOT analysis above, the matrix of SWOT analysis is formulated as follows.

Table 5

SWOT Matrix

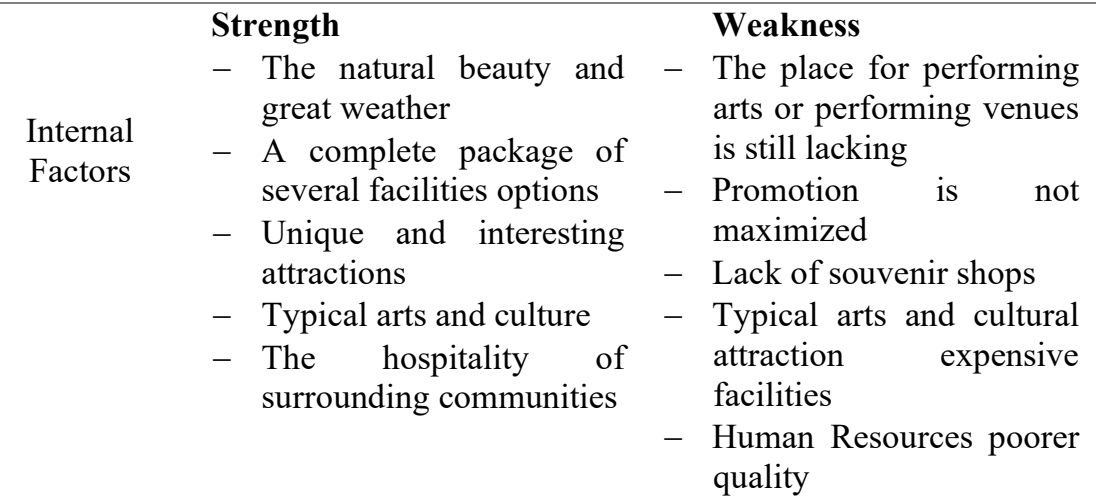




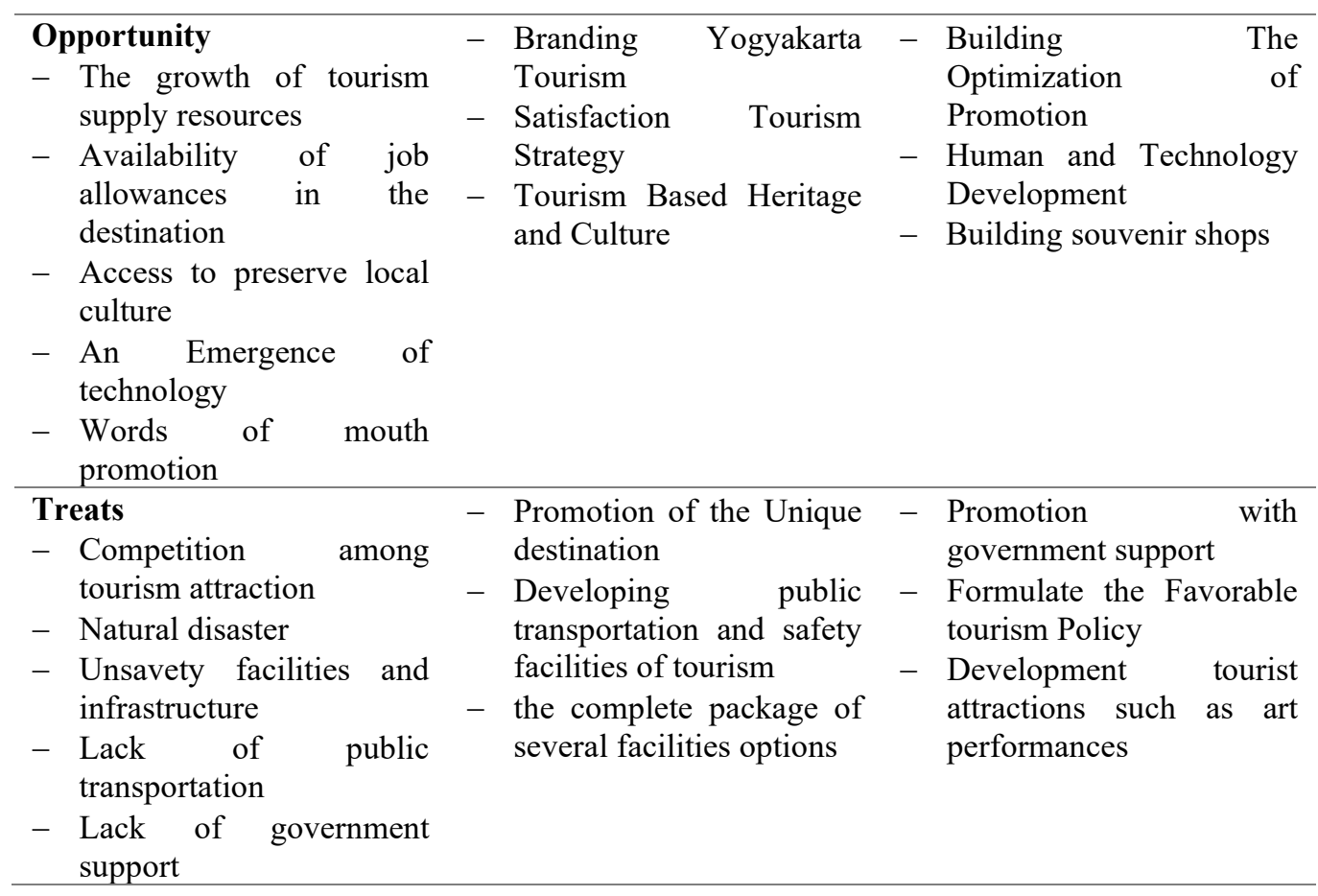

Based on the SWOT Matrix above, it can be formulated for the formulation of alternative strategies in achieving Competitiveness in Yogyakarta Tourism as follows::

- Branding Yogyakarta tourism destination

- Satisfaction tourism strategy

- Tourism based heritage and culture

- Building the optimization of promotion

- Human and technology development

- Building souvenir shops

- Promotion of the unique destination

- Developing public transportation and safety facilities of tourism

- The complete package of several facilities options

- Promotion with government support

- Formulate the favorable tourism policy

- Development tourist attractions such as art performances

\section{Conclusion}

The source of the uniqueness of tourism in Yogyakarta is the culture of Yogyakarta which teaches the relationship between humans and nature, with other people and creators, thereby creating a long-term business continuity. Special of Territory of Yogyakarta are many destinations consists of: Sultan Palace, Malioboro, Beringharjo Traditional Market, Tamansari Water Castle, Museum Sonobodoyo, Taman Pintar, Gembiroloka Zoo, Museum the Matta, are 
of the tourism destination in Yogyakarta City. Merapi mountain, Lava Tour, Prambanan and Boko Temple, Kaliurang, Tubing Breksi are the tourism destination in Sleman Regency. Becici mountain, Parangtritis beach, Depok beach, Parangkusomo beach, Kasongan art market, Slarong Cave, the Flower Garden, is the tourism destination in Bantul Regency. The Pindul Cave, Kalisuci cave, Gunung Api Purba, Indrayanti beach, Baron beach, Krakal beach, Wedo Ombo beach, Srigethuk waterfall are the tourism destination in Gunung Kidul Regency. So the Glagah beach, Bugel beach, Congot beach, Dolan Ndeso, Menoreh mountain are the tourism destination in Kulon Progo.

Based on the analysis of internal and external situations, a score of 6.741 for internal factors is obtained, which means that the competitive position of the Yogyakarta tourism industry is getting stronger and the attractiveness of the industry is getting higher. While the value of External Factors with a score of 6.3135, which means that the Yogyakarta tourism industry can anticipate all threats..

Based on the SWOT Matrix the study formulated an alternative Strategy Competitiveness in the Yogyakarta tourism industry are: branding Yogyakarta tourism destination, satisfaction tourism strategy, tourism based heritage and culture, building the optimization of promotion, human and technology development, building souvenir shops, promotion of the unique destination, developing public transportation and safety facilities of tourism, the complete package of several facilities options, promotion with government support, formulate the favorable tourism policy, and development tourist attractions such as art performances.

\section{References}

[1] Armenska, T., Markovic, V, Davidovic, N., and Jovanovic, T.(2011). Integrated Model of Destination Competitiveness. Geographica Pannonica, 15(2): 58 - 69

[2] Ali, M.M \& Mohsin, S.C.(2008) Different aspects of Tourism Marketing Strategies with Special Reference to Yogyakarta: An Analysis. Business Review: A Journal of Business Administration, Khulna University, 6 (1 \& 2),1-3.

[3] Dwyer L., P. Forsyth, P. Rao (2002) Destination Price Competitiveness: Exchange Rate Changes Vs Inflation Rates. Journal of Travel Research Vol 40, February 2002, 340348 .

[4] Dwyer and Kim, 2003, Destination Competitiveness: Determinants and Indicators, Current Issues in Tourism, Vol. 6, No 5, 2003, 369-414.

[5] Fulad Enda, Kume Fasilika (2013) The Competitive Analysis - The Appropriate Instrument towards a Successful Development. Annual International Interdisciplinary Conference, AIIC 2013, pp 24-26 April, Azores, Portugal

[6] Hassan S. 2000. Determinants of Market Competitiveness in an Environmentally Sustainable Tourism Industry. Journal of Travel Research, Feb. 2000, vol. 38, (3), 239245;

[7] Hossain. B, (2013) Tourism Destination Marketing Case Study-Kuakata Sea Beach, Bangladesh. Thesis, Centria University of Applied Sciences.

[8] Middleton Victor T. C \& Clarke Jackie. 2001. Marketing in Travel and Tourism. Butterworth Heineman: Fourth Edition.

[9] Moon, H.C., Rugman, A.M. \& Verbeke, A. (1998). "The Generalized Double Diamond Approach to International Competitiveness" Research in Global Strategic Management, Volume 5, 97-114. 
[10] Porter, M. E. (1980). "Competitive Strategy: Techniques for Analyzing Industries and Competitors", Free Press, New York.

[11] Porter, M. E. (1985). Competitive advantage: Creating and Sustaining Superior Performance, Free Press, New York

[12] Ritchie, J. B., \& Crouch, G. I. (2005). The Competitive Destination: A Sustainable Tourism Perspective. Wallingford, UK: CABI Publishing

[13] Vanhove, R. (2006). A Comparative Analysis of Competition Models for Tourism Destination. In M. Kozak, \& A. Luisa, Progress in Tourism Marketing (p. 111). Amsterdam: Elsevier.

[14] Wondowossen Tegegne Anteneh, Nobukazu Nakagoshi1, Yotsumoto Yukio, Rob H.G. Jongman, Assefa Zerihun Dawi. (2014). Competitiveness as an Indicator of Sustainable Development of Tourism: Applying Destination Competitiveness Indicators to Ethiopia. Journal of Sustainable Development Studies. ISSN 2201-4268 Volume 6, Number 1, 2014, 71-95 